Article type : Original Article

\title{
Clostridium difficile Infection is Associated with Graft Loss in Solid Organ Transplant Recipients
}

\author{
${ }^{*}$ A. Cusini ${ }^{1,}{ }^{10},{ }^{*}$ C. Béguelin 1 , S. Stampf ${ }^{2}$, K. Boggian ${ }^{3}$, C. Garzoni ${ }^{1,4}$, M. Koller ${ }^{3}$, O. Manuel ${ }^{5}$, P. \\ Meylan $^{5}$, N. J. Mueller ${ }^{6}$, H. Hirsch ${ }^{7}$, M. Weisser ${ }^{7}$, C. Berger ${ }^{8}$, C. van Delden ${ }^{9}$ and the ${ }^{\S}$ Swiss \\ Transplant Cohort Study \\ * These authors participated equally to this work
}

1. Department of Infectious Diseases, Bern University Hospital, University of Bern, Switzerland

2. Clinic for Transplantation Immunology and Nephrology, University Hospital Basel, Switzerland

3. Division of Infectious Diseases \& Hospital Hygiene, Cantonal Hospital St. Gallen, Switzerland

4. Clinic of Internal Medicine \& Infectious Diseases, Clinica Luganese, Lugano, Switzerland

5. Infectious Diseases Service, University Hospital of Lausanne (CHUV), Switzerland

6. Division of Infectious Diseases \& Hospital Epidemiology, University Hospital, University of Zürich, Switzerland

7. Division of Infectious Diseases \& Hospital Epidemiology, University Hospital Basel, Switzerland

8. Division of Infectious Diseases and Hospital Epidemiology, University Children's Hospital Zürich, Switzerland

9. Transplant Infectious Diseases Unit, University Hospitals Geneva, Switzerland

10. Division of Infectious Diseases, Cantonal Hospital Chur, Switzerland

\section{Corresponding author:}

Christian van Delden

Transplant Infectious Diseases Unit

University Hospitals Geneva,

4 rue Gabrielle-Perret-Gentil

This article has been accepted for publication and undergone full peer review but has not been through the copyediting, typesetting, pagination and proofreading process, which may lead to differences between this version and the Version of Record. Please cite this article as doi:

10.1111/ajt.14640

This article is protected by copyright. All rights reserved. 
Phone: 00412237232 07, Fax: 0041223482560 Email: christian.vandelden@hcuge.ch

${ }^{\S}$ The members of the Swiss Transplant Cohort Study are: Rita Achermann, Patrizia Amico, John-David Aubert, Vanessa Banz, Guido Beldi, Christian Benden, Christoph Berger, Isabelle Binet, Pierre-Yves Bochud, Heiner Bucher, Leo Bühler, Thierry Carell, Emmanuelle Catana, Yves Chalandon, Sabina de Geest, Olivier de Rougemont, Michael Dickenmann, Michel Duchosal, Laure Elkrief, Thomas Fehr, Sylvie Ferrari-Lacraz, Christian Garzoni, Paola Gasche Soccal, Christophe Gaudet, Emiliano Giostra, Déla Golshayan, Karine Hadaya, Jörg Halter, Dominik Heim, Christoph Hess, Sven Hillinger, Hans H. Hirsch, Günther Hofbauer, Uyen Huynh-Do, Franz Immer, Richard Klaghofer, Michael Koller (Head of the data center), Bettina Laesser, Roger Lehmann, Christian Lovis, Oriol Manuel, Hans-Peter Marti, Pierre Yves Martin, Pascal Meylan, (Head, Biological samples management group), Paul Mohacsi, Philippe Morel, Ulrike Mueller, Nicolas J Mueller (Chairman Scientific Committee), Helen Mueller-McKenna (Head of local data management), Antonia Müller, Thomas Müller, Beat Müllhaupt, David Nadal, Manuel Pascual (Executive office), Jakob Passweg, Juliane Rick, Eddy Roosnek, Anne Rosselet, Silvia Rothlin, Frank Ruschitzka, Urs Schanz, Stefan Schaub, Aurelia Schnyder, Christian Seiler, Susanne Stampf, Jürg Steiger (Head, Executive Office), Guido Stirnimann, Christian Toso, Christian Van Delden (Executive office), JeanPierre Venetz, Jean Villard, Madeleine Wick (STCS coordinator), Markus Wilhelm, Patrick Yerly.

\author{
Abbreviations \\ CDI, Clostridium difficile infection \\ eCRF, electronic case report form \\ ESCMID, European Society for Clinical Microbiology and Infectious Diseases \\ ICU, intensive care unit \\ $\mathrm{PH}$, proportional hazard \\ PPI, proton-pump inhibitor \\ SOT, solid organ transplant recipients \\ STCS, Swiss Transplant Cohort Study
}

This article is protected by copyright. All rights reserved. 


\section{Abstract:}

Clostridium difficile infection (CDI) is a leading cause of infectious diarrhea in solid organ transplant recipients (SOT). We aimed to assess incidence, risk factors and outcome of CDI within the Swiss Transplant Cohort Study (STCS). We performed a case-control study of SOT recipients in the STCS diagnosed with CDI between May 2008 and August 2013. We matched two control subjects per case by age at transplantation, sex and transplanted organ. A multivariable analysis was performed using conditional logistic regression to identify risk factors and evaluate outcome of CDI. Two thousand one hundred and fifty-eight SOT recipients, comprising 87 cases of $\mathrm{CDI}$ and 174 matched controls were included. The overall CDI rate per 10'000 patient days was 0.47 (95\% confidence interval $(\mathrm{Cl})$ : $[0.38,0.58])$, with the highest rate in lung $(1.48,95 \% \mathrm{Cl}:[0.93,2.24])$. In multivariable analysis, proven infections (hazard ratio $(\mathrm{HR}) 2.82,95 \% \mathrm{Cl}:[1.29,6.19])$ and antibiotic treatments $(\mathrm{HR}=4.51$, $95 \% \mathrm{Cl}:[2.03,10.0])$ during the preceding three months were independently associated with the development of CDI. Despite mild clinical presentations, recipients acquiring CDI posttransplantation had an increased risk of graft loss $(\mathrm{HR}=2.24,95 \% \mathrm{Cl}:[1.15,4.37], \mathrm{p}=0.02)$. These findings may help to improve the management of SOT recipients.

\section{Introduction}

Clostridium difficile is a leading cause of infectious diarrhea with a reported incidence rate of 7 cases per 10'000 patient-bed days in Europe (1). Solid organ transplant (SOT) recipients are at higher risk for CDI than the general population, due to numerous risk factors including severe underlying diseases, immunosuppression, recent surgery, antibiotic treatment, ganciclovir prophylaxis, gastric acid suppression and prolonged hospital stay (2-5). A recently published meta-analysis in SOT recipients reported an overall prevalence of $7.4 \%$ (6). The clinical spectrum of CDI ranges from asymptomatic colonization to fulminant pseudomembranous colitis. Knowledge about the severity of CDI and the impact on graft function in SOT is scarce and contradictory; while some authors have described a worse outcome of CDI in SOT recipients $(2,4,5,7,8)$, a recent Spanish cohort study and two US studies reported a good prognosis of CDI in SOT recipients (9-11). These aspects are This article is protected by copyright. All rights reserved. 
important, as newer treatment guidelines for CDI stratify according to the clinical severity of disease emphasizing the reduction of recurrence of $\operatorname{CDI}(12,13)$. Indeed, whereas both oral metronidazole and vancomycin were equally effective for treatment of mild CDI, response rates were superior for vancomycin in patients with severe CDI in a randomized trial (14). Accordingly, the recently updated guidelines of the European Society for Clinical Microbiology and Infectious Diseases (ESCMID) and the latest US-American guidelines recommend as first option oral metronidazole for patients with non-severe and oral vancomycin for severe $\operatorname{CDI}(12,13)$. Fidaxomicin achieved significantly lower rates of recurrence of CDI in two clinical trials $(15,16)$. Accordingly, the ESCMID guidelines recommend the use of fidaxomicin for patient at risk for recurrent CDI (13).

Our main objective was to determine the outcome of CDI in SOT recipients. Secondary aims were to describe incidence and clinical severity, and to identify risk factors for CDI within this population.

\section{Methods}

\section{Patients and study design}

The Swiss Transplant Cohort Study (STCS) is an observational national cohort, enrolling all SOT recipients followed at six Swiss university centers. Details on data definitions and the cohort structure have been previously published $(17,18)$. For the present study, all SOT recipients prospectively enrolled in the STCS between May 2008 and August 2013 with written informed consent were included. The protocol was approved by the ethics committee of all participating centers. Patient's data were collected in the STCS database at enrollment, 6 and 12 months, and yearly after transplantation on standardized electronic case report forms (eCRF). Clinical data extracted from the STCS database included demographic data, infections, antibiotic and antiviral prophylaxis, induction and maintenance immunosuppressive treatments, as well as medical co-morbidities and surgical complications. To analyze risk factors that are not routinely registered in the STCS database

This article is protected by copyright. All rights reserved. 
we performed a nested case-control study, applying an incidence density sampling matching two controls to each case by age at transplantation (differences $\leq 10$ years), sex and type of transplant. Controls were defined as SOT recipients without captured CDI in the SCTS database. The non-occurrence of CDI in these recipients was double checked in the hospital charts and local laboratory databases. For all cases and controls we extracted additional data including type of anti-infective treatment in the three months preceding CDI (19), intake of a proton-pump inhibitor (PPI), as well as hospital and intensive care unit (ICU) stay from the local laboratory databases and hospital charts, and captured them in dedicated eCRF. For cases, we additionally collected the clinical severity of CDI classified in three categories (definition see below), hospital and ICU admission due to CDI, peak white blood count, platelet nadir, rise in serum creatinine and the antibiotic treatment for CDI. There were no clinical variables with missing data included in the multivariable analyses.

\section{Definitions}

To assure homogeneous assessment of the infectious disease events in the STCS, specifically trained infectious diseases specialists at each center record the occurrence of infectious events using standardized definitions (17). Proven CDI was defined according to the criteria of the STCS Infectious Diseases Working Group as follows: presence of symptoms (diarrhea) and/or clinical signs (evidence of pathologic findings in endoscopy or radiology) together with pathogen isolation (by culture, or antigen) and Clostridium difficiletoxin detection. CDI clinical severity was graded (mild-to-moderate / severe disease / severe and complicated disease) as proposed by the American College of Gastroenterology in 2013, without considering the serum albumin level, since this value was available only for a minority of patients (12). Mild-to-moderate disease was defined as diarrhea with any additional signs or symptoms not meeting criteria of severe or complicated diarrhea. Severe disease included abdominal tenderness or leucocytosis $>15^{\prime} 000$ cells $/ \mathrm{mm}^{3}$. Severe and

This article is protected by copyright. All rights reserved. 
complicated disease required one or more of the following criteria: ICU admission for CDI, hypotension, fever $>38.5^{\circ}$, paralytic ileus or significant abdominal distension, mental status changes, leucocytosis $>35 \mathrm{G} / \mathrm{l}$ or leucopenia $<2 \mathrm{G} / \mathrm{l}$, serum lactate levels $>2.2 \mathrm{mmol} / \mathrm{l}$, and end organ failure. Clinical recurrence was defined as reappearance of diarrhea after the cessation of therapy, isolation of $C$. difficile or its toxin in stool, and need for retreatment. No distinction between relapse and reinfection was possible, since the $C$. difficile strains were not available for further analysis. Infections in the three months before CDI were defined according to the criteria of the STCS Infectious Diseases Working Group. A proven bacterial infection required a pathogen isolated together with clinical signs and/or symptoms and treatment given. A proven viral disease required detection of virus replication with corresponding pathology in biopsy tissues. A viral syndrome consisted of detection of virus replication and non-organ-specific clinical symptoms. For fungal infections, we used the EORTC/MSG Consensus Group definitions (20). We defined graft loss as follows: recurrence of insulin-dependence following pancreas transplant, dialysis post-renal transplant, retransplantation post-heart, liver or lung transplant. All-cause mortality, and mortality assumed to be related to CDI were collected separately.

\section{Statistical analysis}

Patients' baseline characteristics are shown descriptively, separated for patients with and without CDI. CDI-specific information for patients with at least one CDI episode, follow-up and outcome information are also presented. Cumulative incidence rates for the first CDI episode were calculated by transplant type, treating death before CDI as competing risk. Based on the case-control study, risk factors for CDI post-SOT were investigated in univariate and multivariable conditional logistics regression models. We determined risk exposure either at time of transplantation, or when adequate three months prior to first CDI occurrence within the case-control study. Due to the large number of potential risk factors and the relatively low number of CDI events, we used the conservative Bonferroni method to adjust for the multiple testing problem. The final multivariable model, restrained to generic

This article is protected by copyright. All rights reserved. 
terms, was based both on the univariate analysis and on clinical relevance of potential risk factors, excluding hospitalization because of an excessively large confident interval. We also investigated the probability for recurrent CDI episodes using logistic regression models without further risk adjustment.

We further performed Cox proportional hazard $(\mathrm{PH})$ models to evaluate the effect of $\mathrm{CDI}$ on the occurrence of graft loss and death. We applied non-informative censoring about the outcome (death, graft loss). CDI was considered as time-dependent risk factor in time-toevent analyses. In addition to CDI, we included baseline and time-dependent risk factors (surgical complications, medical problems, rejection, and relevant infections) in the graft loss analysis (Table 5). The $\mathrm{PH}$ assumption was verified by plotting Schoenfeld residuals to visualize the effect over time. When the $\mathrm{PH}$ assumption was violated, but the effect strong and without change of the direction, no restrictions were included and the interpretation not hampered. All statistical analyses were performed using the statistical software R (version 3.2.0; R Foundation for Statistical Computing, Vienna, Austria).

\section{Results:}

\section{Population characteristics and incidence of CDI}

During the observation period, 2400 SOTs were performed in Switzerland. After exclusion of combined transplants and patients who did not sign the informed consent, we included 2158 patients (1261 kidney, 454 liver, 224 lung, 164 heart and 55 kidney-pancreas recipients) in the present study. Within the study population, we identified 87 patients (cases) with 102 proven CDI episodes corresponding to a crude incidence of $4.0 \%$. CDI was observed in 35 kidney, 23 liver, 22 lung and 7 heart recipients (Table 1). The cumulative incidence rate for the first CDI episode per patient at one year post SOT was 0.09 for lung, 0.05 for liver, 0.04 for heart and 0.02 for kidney recipients (Figure 1). The overall CDI rate was $0.47(95 \% \mathrm{Cl}$ : [0.38-0.58]) per 10'000 patient-days. Lung recipients had the highest (1.48, [0.93-2.24]) and kidney recipients the lowest rate $(0.30,[0.21-0.41])$. Almost all CDI events occurred in the first year following transplantation. The median time-lag from transplant to CDI was 70 days

This article is protected by copyright. All rights reserved. 
(interquartile range (IQR): [21-189]). Lung recipients had the shortest time-lag (31 days, IQR: [7-129]), whereas kidneys had the longest (115 days, IQR: [38-308]). Acquisition of CDI was nosocomial in $49(56 \%)$ patients. CDI diagnosis in the $102 \mathrm{CDI}$ episodes was based on culture and toxin detection ( $\mathrm{N}=60)$, antigen and toxin detection $(\mathrm{N}=24)$ and exclusively Clostridium difficile-toxin detection by PCR $(\mathrm{N}=18)$.

\section{Risk factors for CDI development}

In univariate analysis, infections, especially proven bacterial infections, anti-infective therapy, antibiotic therapy, all B-lactams and quinolones, and hospitalization in the three months preceding the event were associated with the development of CDI (Table 2). In the multivariable analysis, infections (odds ratio (OR) 2.82, 95\% Cl: $[1.29,6.19], p=0.01$ ) and intake of antibiotic treatments $(\mathrm{OR}=4.51,95 \% \mathrm{Cl}$ : $[2.03,10.00], \mathrm{p}<0.001)$ during the three months preceding the event remained significantly associated with CDI development.

\section{Treatments}

Seventy-one (83.5\%) cases were treated with metronidazole for a median duration of 11 days (IQR: $[10,15]), 10(11.8 \%)$ cases were treated with oral vancomycin for a median duration of 11 days (IQR: $[10,13])$ and $4(4.7 \%)$ cases received a combined treatment with metronidazole and vancomycin (Table 3). Two cases with a mild course of CDI recovered spontaneously without any treatment. Recurrent CDI was treated by metronidazole in 9 , vancomycin in 2 cases, and combination therapy in 3 cases.

\section{Clinical severity and recurrence}

Sixty-five of 87 cases $(74.7 \%)$ had a mild to moderate, $19(21.8 \%)$ a severe, and $3(3.4 \%)$ a severe complicated course of CDI (Table 3). Seventeen (19.5\%) patients required hospital admission and one patient ICU admission for treatment of the CDI. The median white blood cell count at the time of diagnosis was $8.9 \mathrm{G} / \mathrm{L}$ (IQR: [5.5, 11.3]), with 43 (51\%) patients having a value outside the normal range of $4-10 \mathrm{G} / \mathrm{l}$. Four-teen $(16.1 \%)$ patients experienced 
more than a single CDI event, 13 patients had 2 events and one patient 3 events. The median time between the first and the second event was 56 days ( $\min =14, \max =1127) .10$ of 14 recurrent $\mathrm{CDI}$ occurred within 8 weeks after the first episode. In univariate logistic regression, we found no significant differences in age, gender, transplant type, clinical severity and treatment for $1^{\text {st }} \mathrm{CDI}$ between patients with single and recurrent CDI episodes. (Table 3).

\section{Outcome analysis}

Two hundred three out of 2158 SOT recipients died, including 14 out of 87 CDI cases $(9.1 \%$ versus $16.1 \%$, Tables 1 and 4 ). No death was directly linked to CDI. Two deaths occurred within three months following CDI. In univariate analysis, patients who died were older (56 versus 49 years, $\mathrm{p}<0.001$ ) and patients transplanted for heart, liver and lung had a higher risk to die compared to kidney recipients $(p<0.001)$ (Table 6). This was confirmed in multivariable analysis. CDI increased mortality in univariate analysis $(\mathrm{HR}=2.31 ; 95 \% \mathrm{Cl}$ : $[1.33,3.99], p=0.003)$, however this effect was no longer significant in the multivariable model (HR=1.63, 95\% Cl: [0.94, 2.83], $\mathrm{p}=0.085)$ (Table 6).

In univariate analysis for graft loss, baseline recipient characteristics (age, gender, transplant) showed no significant effects $(p>0.05)$ (Table 6). In contrast, the occurrence of $\mathrm{CDI}$ was associated with graft loss (HR=3.72, 95\% $\mathrm{Cl}$ : $[1.92,7.20], \mathrm{p}<0.001)$. To confirm this effect, we accounted for further time-dependent risk factors potentially associated with graft loss. These included general and transplant specific surgical complications, medical problems, rejection, and both systemic and transplant specific infections (Table 5). Combined surgical complications, medical problems, relevant infections, as well as both bacterial and fungal infections analyzed alone or in combination were all significantly associated with graft loss in univariate analyses (Table 6). In contrast, viral infections, including or not CMV, did not increase the risk of graft loss. In a multivariable model, surgical complications $(H R=7.22$, 95\% Cl: [4.53, 11.50], $\mathrm{p}<0.001)$, medical problems (HR=2.35, 95\% Cl: [1.33, 4.15], $\mathrm{p}=0.003)$, rejection ( $\mathrm{HR}=7.56,95 \% \mathrm{Cl}:[4.70,12.18], \mathrm{p}<0.001)$, bacterial and fungal infections 
$(\mathrm{HR}=3.67,95 \% \mathrm{Cl}:[2.22,6.06], \mathrm{p}<0.001)$, as well as $\mathrm{CDI}(\mathrm{HR}=2.24,95 \% \mathrm{Cl}:[1.15,4.37]$, $p=0.02$ ) remained independent risk factors for graft loss (Table 6).

\section{Discussion}

We report the results of a nationwide study of 87 cases of Clostridium difficile infections among 2158 SOT recipients in the STCS. We identified and confirmed preceding infection and antibiotic use as risk factors for CDI. We showed that despite most episodes being clinically benign, CDI was associated with a 2.2-fold increased risk of graft loss.

The crude incidence of CDI in our prospectively evaluated cohort including $>90 \%$ of all Swiss SOT recipients was $4 \%$ corresponding to an infection rate of 0.47 per 10000 patient-days. This incidence is low as compared to previous reports, including a meta-analysis comprising 30 studies reporting an overall incidence of $7.4 \% \mathrm{CDI}$ in SOT recipients (6). Methodological differences in calculating the occurrence of CDI in SOT might explain such differences. Of note the incidence of $\mathrm{CDI}$ in the general Swiss population in hospitals compares to other European countries ( 4.8 cases vs 4.1 cases per 10'000 patients-days, respectively) (21). In accordance with earlier reports, lung recipients had the highest incidence rate as well as the earliest occurrence after transplantation $(4,5,9,22)$. Consequently, some authors have suggested to implement metronidazole as prophylaxis early after lung transplantation (23).

Of major importance is our observation that despite low clinical severity and good therapeutic response, CDI in SOT recipients was associated with an increased risk of graft loss. An impact on graft function has been previously suggested for non-infectious diarrhea (24), but to our knowledge was never associated with CDI. The therapeutic efficacy of fecal transplantation in the treatment of CDI highlights the importance of CDI as a marker of intestinal dysbiosis $(25,26)$. It is likely, that whereas the immune dysregulation is the initial insult leading to intestinal dysbiosis in SOT recipients, potentially further worsened by antibiotic treatments (27), CDI aggravates this intestinal microbial imbalance. Inflammation

This article is protected by copyright. All rights reserved. 
associated with CDI could also provoke graft rejection via innate immune mechanisms. In such a scenario, dysbiosis or the $C$. difficile itself could enhance $\mathrm{TH}$-responses affecting the graft. However, whether CDI itself or this exacerbated intestinal dysbiosis increases the risk of graft loss is impossible to distinguish at this point. Diarrhea and intestinal dysbiosis could both interfere with adequate absorption and/or the metabolism of immunosuppressive agents, thereby increasing the risk for graft failure. The higher rates of graft loss and death in CDI cases could also be an indirect marker of sicker patients and an unfavorable posttransplantation course, as evidenced by the higher numbers of infections and antibiotic administration in cases compared to controls in this study, rather than a direct effect of the CDI. In line with this hypothesis is the recent report describing a higher number of organ specific complications among SOT recipients (28). Further prospective studies, analyzing $\mathrm{CDI}$ and microbiome changes, as well as immune responses will be needed to deceiver the type of association between CDI and graft loss, and its underlying mechanisms.

All infectious disease events are systematically collected in the STCS. This allowed us to identify previous bacterial, but not viral and fungal, infections that occurred during the preceding three months as major risk factors for CDI development. Clearly, we confirm antibiotic treatments, including carbapenems, cephalosporins, quinolones and penicillins, as a significant risk factor $(\mathrm{OR} \geq 4)$ in $\mathrm{SOT}$ recipients for developing CDI. Still, as previously noted, $25 \%$ of patients with CDI had not received antibiotics in the last 3 months (27). In these cases, the development of $\mathrm{CDI}$ has been suggested to be linked to immune dysfunction in SOT recipients (27). As in the Spanish cohort, we found no association with induction therapy or with different immunosuppression regimens (9).

In our study, $75 \%$ of CDI episodes were mild to moderate, 3 cases $(3.4 \%)$ had a severe complicated course, and no patient required a surgical intervention or died due to CDI. This is a more benign course as compared to previously published data reporting $5.3 \%$ complicated cases (6). The severity of CDI has been shown to depend on the presence of circulating hyper-virulent strains such as ribotype 027 (29). It is likely that the favorable outcome in the present report may be linked to a low prevalence of hyper-virulent ribotypes

This article is protected by copyright. All rights reserved. 
in Switzerland (30). In correlation with the low clinical severity, most of our cases (83.5\%) were treated with metronidazole for a medium duration of 11 days according to current guidelines (27). CDI recurred in $16.1 \%$ cases, less frequently as compared to $19.7 \%$ reported in the literature (6). In the absence of genotyping differentiation between relapses and reinfections was not possible. However, 59\% of the recurrent CDI episodes occurred within 8 weeks after the first suggesting these second events to be relapses rather than reinfections.

Our study has some limitations. The CDI incidence rate may be underestimated, especially for CDI episodes that could have occurred outside the transplant centers. However, most CDIs occurred early after transplant when SOT recipients were in close contact with the transplant center and we suppose that only very few events have been missed. The use of different diagnostic tests, including culture, detection of antigens and Clostridium difficiletoxin, by enzyme immune assay and PCR might also have affected incidence rates. Despite our study being one of the largest series of CDI in SOT recipients published to date (6), the number of CDI per transplant remained small and required pooling of specific risk factors in the multivariable analysis.

The strength of our study remains the comprehensive nationwide enrolment of all Swiss SOT recipients, which guaranties highly representative data of the real-life situation in Switzerland. In conclusion, preceding bacterial infections and antibiotic treatment were risk factors for the development of CDI after SOT. Despite mild clinical presentation, and good clinical responses, SOT recipients with CDI were at increased risk for graft loss. These data support the importance of restrictive antibiotic use in the prevention of CDI and underlines the need for close surveillance of graft function in SOT recipients developing CDI. Further studies are needed to assess the impact of CDI on allograft function.

This article is protected by copyright. All rights reserved. 


\section{Acknowledgments}

Thanks: We thank all patients, doctors, and nurses associated with the Swiss Transplant Cohort Study (STCS), and Dionysios Neofytos for critical review and editing the manuscript. Funding: This study has been conducted in the framework of the Swiss Transplant Cohort Study, supported by the Swiss National Science Foundation and the Swiss University Hospitals (G15) and transplant centers. Data quality audits are funded by the Federal Office of Public Health of Switzerland.

The study was additionally funded by Astellas with an unrestricted grant.

Author contributions: A.C. was involved in concept, design, data analysis and interpretation, writing of the article. C.B. contributed to data collection, data analysis and interpretation, and writing of the article. S.S. performed data analysis and statistics. C.V.D. contributed to concept, design, and writing of the article. C.B, K.B., C.G., O.M., P.R.A.M., N.J.M contributed to data collection and critical revision of the article.

\section{Disclosure}

The authors of this manuscript have no conflicts of interest to disclose as described by the American Journal of Transplantation.

\section{Figure legends:}

Figure 1. Cumulative incidences of first CDI episodes according to transplant.

Shown are the two-year cumulative incidences of first episodes of $C$. difficile infections in 87 SOT recipients with CDI according to allograft type.

This article is protected by copyright. All rights reserved. 
Tables:

Table 1. Characteristics of 2158 SOT recipients according to CDI

\begin{tabular}{|l|c|c|}
\hline & Recipients with CDI & Recipients without CDI \\
\hline Number of SOT recipients, N (\%) & $87(4.0)$ & $2071(96.0)$ \\
\hline Age at transplantation, mean (SD) & $52.9(14.6)$ & $49.6(16.1)$ \\
\hline Male, N (\%) & $50(57.5)$ & $1329(64.2)$ \\
\hline Type of transplantation, N (\%) & & $1226(59.2)$ \\
\hline Kidney & $35(40.2)$ & $525(42.8)$ \\
\hline Living donation & $8(22.9)$ & $431(20.8)$ \\
\hline Liver & $23(26.4)$ & $26(6)$ \\
\hline Living donation & $2(8.7)$ & $202(9.8)$ \\
\hline Lung & $22(25.3)$ & $157(7.6)$ \\
\hline Heart & $7(8.0)$ & $55(2.7)$ \\
\hline Kidney - Pancreas & $0(0.0)$ & $2.3[1.1,3.5]$ \\
\hline Diabetes mellitus, N (\%) & $20(23)$ & $117(5.6)$ \\
\hline Follow-up time (yrs), median [IQR] & $3.3[1.9,4]$ & \\
\hline $\begin{array}{l}\text { Graft loss, N (\%) } \\
\text { before CDI } \\
\text { after CDI }\end{array}$ & $14(16.1)$ & $189(9.1)$ \\
\hline Death, N (\%) & $4(4.6)$ & \\
\hline
\end{tabular}

This article is protected by copyright. All rights reserved. 
Table 2: Risk factors for CDI

\begin{tabular}{|c|c|c|c|c|}
\hline $\begin{array}{l}\text { Risk exposure at or within three months } \\
\text { prior to CDI }\end{array}$ & $\begin{array}{l}\text { Cases } \\
(n=87)\end{array}$ & $\begin{array}{l}\text { Controls } \\
(n=174)\end{array}$ & $\begin{array}{l}\text { Univariate } \\
\text { OR [95\%Cl] } \\
\text { adj. p-value }\end{array}$ & $\begin{array}{l}\text { Multivariable } \\
\text { OR [95\%Cl] } \\
\text { adj. p-value }\end{array}$ \\
\hline $\begin{array}{l}\text { Infections, } \mathbf{N}(\%) \\
{\left[\text { Mean number per patient }{ }^{*},(\min , \max )\right]}\end{array}$ & $\begin{array}{c}46(52.9) \\
{[1.72,(1,8)]}\end{array}$ & $\begin{array}{c}35(20.1) \\
{[1.31,(1,4)]}\end{array}$ & $\begin{aligned} 5.10 & {[2.70,9.63] } \\
& <0.001\end{aligned}$ & $\begin{array}{c}2.82[1.29,6.19] \\
0.01\end{array}$ \\
\hline - Proven bacterial infections & $36(41.4)$ & $26(14.9)$ & $\begin{array}{c}4.25[2.21,8.16] \\
<0.001\end{array}$ & \\
\hline - Proven viral infections \& viral syndromes & $13(14.9)$ & $8(4.6)$ & $\begin{array}{c}3.09[1.27,7.49] \\
0.379\end{array}$ & \\
\hline - Proven or probable fungal infections & $7(8.0)$ & $4(2.3)$ & $\begin{array}{c}3.50[1.03,11.96] \\
1\end{array}$ & \\
\hline Anti-infective prophylaxis, N (\%) & $68(78.2)$ & $130(74.7)$ & $1.37[0.63,2.99]$ & $\begin{array}{l}0.96[0.36,2.57] \\
0.936\end{array}$ \\
\hline Anti-infective therapy, N (\%) & 69 (79.3) & 70 (40.2) & $\begin{array}{c}7.96[3.72,17.02] \\
<0.001\end{array}$ & \\
\hline Antibiotics, N (\%) & $65(74.7)$ & $61(35.1)$ & $\begin{array}{c}7.41[3.60,15.26] \\
<0.001\end{array}$ & $\begin{aligned} 4.51 & {[2.03,10.00] } \\
& <0.001\end{aligned}$ \\
\hline $\begin{array}{l}\text { - Penicillins, } \mathrm{N}(\%) \\
\text { [duration (days), median (IQR)] }\end{array}$ & $\begin{array}{l}42(48.3) \\
{[9,(7,14)]}\end{array}$ & $\begin{array}{c}33(19) \\
{[9,(6,14)]}\end{array}$ & $\begin{array}{l}4.34[2.28,8.28] \\
<0.001\end{array}$ & \\
\hline - Cephalosporins, N (\%) & $\begin{array}{l}19(21.8) \\
{[7,(5,10)]}\end{array}$ & $\begin{array}{c}11(6.3) \\
{[10,(5,16)]}\end{array}$ & $\begin{array}{c}4.47[1.84,10.86] \\
0.028\end{array}$ & \\
\hline - Carbapenems, N (\%) & $\begin{array}{l}27(31.0) \\
{[9,(6,14)]}\end{array}$ & $\begin{array}{l}21(12.1) \\
{[9,(9,14)]}\end{array}$ & $\begin{array}{c}5.80[2.33,14.45] \\
0.005\end{array}$ & \\
\hline - Quinolones, N (\%) & $\begin{array}{l}24(27.6) \\
{[13,(6,19)]}\end{array}$ & $\begin{array}{c}14(8.0) \\
{[10,(6,13)]}\end{array}$ & $\begin{array}{l}4.00[1.95,8.22] \\
0.005\end{array}$ & \\
\hline - Glycopeptides, N (\%) & $\begin{array}{c}10(11.5) \\
{[15,(7,29)]}\end{array}$ & $\begin{array}{l}15(8.6) \\
{[9,(6,15)]}\end{array}$ & $1.26[0.50,3.19]$ & \\
\hline - Other antibiotics, N (\%) & $\begin{array}{l}19(21.8) \\
{[9,(6,29)]}\end{array}$ & $\begin{array}{c}15(8.6) \\
{[9,(4,21)]}\end{array}$ & $\begin{array}{c}2.85[1.37,5.92] \\
0.153\end{array}$ & \\
\hline Antiviral therapy, N (\%) & $24(27.6)$ & $21(12.1)$ & $\begin{array}{c}3.08[1.51,6.29] \\
0.061\end{array}$ & $\begin{array}{c}1.55[0.65,3.70] \\
0.32\end{array}$ \\
\hline Antifungal therapy, $\mathrm{N}(\%)$ & $14(16.1)$ & $10(5.7)$ & $\begin{array}{c}2.97[1.28,6.89] \\
0.341\end{array}$ & $\begin{array}{l}1.12[0.40,3.10] \\
0.829\end{array}$ \\
\hline Proton pump inhibitor (PPI), N (\%) & $84(96.6)$ & $155(89.1)$ & $\begin{array}{c}3.63[1.02,12.92] \\
1\end{array}$ & $\begin{array}{l}1.25[0.24,6.43] \\
0.788\end{array}$ \\
\hline Hospitalization, N (\%) & $85(97.7)$ & 125 (71.9) & $\begin{array}{c}41.18[5.56,305.10] \\
0.008\end{array}$ & \\
\hline ICU stay, N (\%) & $58(66.7)$ & $91(52.3)$ & $\begin{array}{c}3.61[1.57,8.31] \\
0.077\end{array}$ & $\begin{array}{c}2.34[0.83,6.61] \\
0.108\end{array}$ \\
\hline Induction therapy, N (\%) & $59(67.8)$ & $116(66.7)$ & $\begin{array}{c}1.06[0.59,1.90] \\
1\end{array}$ & $\begin{array}{l}0.75[0.32,1.72] \\
0.491\end{array}$ \\
\hline \multicolumn{5}{|l|}{ Immunosuppression at time of CDI } \\
\hline - Corticosteroid, N (\%) & $76(87.4)$ & 146 (83.9) & $\begin{array}{c}1.39[0.62,3.14] \\
1\end{array}$ & \\
\hline - Calcineurin inhibitors, $\mathrm{N}(\%)$ & $82(94.3)$ & $154(88.5)$ & $2.23[0.79,6.33]$ & \\
\hline - Antimetabolites, N (\%) & $80(92.0)$ & $152(87.4)$ & $1.67[0.69,4.14]$ & \\
\hline
\end{tabular}

This article is protected by copyright. All rights reserved. 


\begin{tabular}{|c|c|c|c|c|}
\hline - mTOR-inhibitors, N(\%) & $8(9.2)$ & $8(4.6)$ & $\begin{array}{c}2.11[0.76,5.89] \\
1\end{array}$ & $\begin{array}{c}2.30[0.63,8.40] \\
0.206\end{array}$ \\
\hline
\end{tabular}

* Mean number of infections in patients with at least one infection.

Table 3. Clinical variables and course of patients with single and multiple CDI events

\begin{tabular}{|c|c|c|c|c|}
\hline & Single CDI & Multiple CDI & Total & p-value* \\
\hline Total $\mathbf{N}$ & 73 & 14 & 87 & \\
\hline Male, N (\%) & $39(53.4)$ & $11(78.6)$ & $50(57.5)$ & 0.09 \\
\hline Age at transplant, mean (SD) & $52.3(14.7)$ & $56.1(13.8)$ & $52.9(14.6)$ & 0.37 \\
\hline Transplanted organ, $\mathbf{N}(\%)$ & & & & 0.88 \\
\hline Heart & $7(9.6)$ & $0(0)$ & $7(8.0)$ & \\
\hline Kidney & $30(41.1)$ & $5(35.7)$ & $35(40.2)$ & \\
\hline Liver & $19(26.0)$ & $4(28.6)$ & $23(26.4)$ & \\
\hline Lung & $17(23.3)$ & $5(35.7)$ & $22(25.3)$ & \\
\hline Clinical course, $\mathbf{N}(\%)$ & & & & 0.76 \\
\hline Mild - moderate & $55(75.3)$ & $10(71.4)$ & $65(74.7)$ & \\
\hline Severe & $16(21.9)$ & $3(21.4)$ & $19(21.8)$ & \\
\hline Severe with complication & $2(2.7)$ & $1(7.1)$ & $3(3.4)$ & \\
\hline WBC (G/I) at 1st CDI, median [IQR] & $8.9[5.8,10.8]$ & $7.3[4.2,19.9]$ & $8.9[5.5,11.3]$ & 0.88 \\
\hline out of range 4-10 G/l, N (\%) & $34(46.6)$ & $9(64.3)$ & $43(49.4)$ & \\
\hline Treatment of 1st CDI, N (\%) & $71(97.3)$ & $14(100)$ & $85(97.7)$ & 0.99 \\
\hline Metronidazole & $62(87.3)$ & $9(64.3)$ & $71(83.5)$ & \\
\hline Vancomycin & $8(11.0)$ & $2(14.3)$ & $10(11.8)$ & \\
\hline Metronidazole and Vancomycin & $1(1.4)$ & $3(21.4)$ & $4(4.7)$ & \\
\hline
\end{tabular}

IQR, interquartile range; SD, standard deviation

${ }^{*} p$-values from unadjusted logistic models for probability of $2^{\text {nd }} \mathrm{CDI}$ event

This article is protected by copyright. All rights reserved. 
Table 4. Characteristics of 2158 SOT recipients for outcome analysis

\begin{tabular}{|c|c|c|}
\hline & Recipients with graft loss & Recipients without graft loss \\
\hline Number of SOT recipients, N (\%) & $131(6.1)$ & 2027 (93.9) \\
\hline \multicolumn{3}{|c|}{ Baseline characteristics } \\
\hline Age at transplantation, mean (SD) & $51.5(14.8)$ & $49.7(16.1)$ \\
\hline Male, N (\%) & $85(63.9)$ & $1294(63.8)$ \\
\hline \multicolumn{3}{|l|}{ Type of transplantation, $\mathbf{N}(\%)$} \\
\hline Kidney (incl. Kidney-Pancreas) & $80(61.1 \%)$ & $1236(61 \%)$ \\
\hline Liver & $26(19.8 \%)$ & $428(21.1 \%)$ \\
\hline Lung & $13(9.9 \%)$ & $211(10.4 \%)$ \\
\hline Heart & $12(9.2 \%)$ & $152(7.5 \%)$ \\
\hline Diabetes mellitus at TX, N (\%) & $26(19.8 \%)$ & $341(16.8 \%)$ \\
\hline Hypertension at TX, N (\%) & $72(55 \%)$ & $1187(58.6 \%)$ \\
\hline \multicolumn{3}{|c|}{ Time-dependent characteristics (until death, graft loss or censoring) } \\
\hline CDI in FUP, $\mathbf{N}(\%)$ & $10(7.6 \%)$ & $73(3.6 \%)$ \\
\hline Surgical complications in FUP, N (\%) & $29(22.1 \%)$ & $127(6.3 \%)$ \\
\hline Medical problems in FUP, N (\%) & $16(12.2 \%)$ & $231(11.4 \%)$ \\
\hline Rejections in FUP, N (\%) & $64(48.9 \%)$ & $715(35.3 \%)$ \\
\hline \multirow[t]{2}{*}{ Bacterial/Fungal ID in FUP, $\mathbf{N}(\%)$} & $46(35.1 \%)$ & $593(29.3 \%)$ \\
\hline & Alive & Deaths \\
\hline Number of SOT recipients, N (\%) & $1955(90.6 \%)$ & $203(9.4 \%)$ \\
\hline \multicolumn{3}{|c|}{ Baseline characteristics } \\
\hline Age at transplantation, mean (SD) & $49.11(16.25)$ & $56.1(12.37)$ \\
\hline Male, N (\%) & $1245(63.7 \%)$ & $134(66 \%)$ \\
\hline \multicolumn{3}{|l|}{ Type of transplantation, $\mathbf{N}(\%)$} \\
\hline Kidney (incl. Kidney-Pancreas) & $1248(63.8 \%)$ & $68(33.5 \%)$ \\
\hline Liver & $395(20.2 \%)$ & $59(29.1 \%)$ \\
\hline Lung & $176(9 \%)$ & $48(23.6 \%)$ \\
\hline Heart & $136(7 \%)$ & $28(13.8 \%)$ \\
\hline \multicolumn{3}{|c|}{ Time-dependent characteristics (until death or censoring) } \\
\hline CDI in FUP, $\mathbf{N}(\%)$ & $73(3.7 \%)$ & $14(6.9 \%)$ \\
\hline
\end{tabular}

This article is protected by copyright. All rights reserved. 
Table 5: Definitions and description of time-dependent risk factors

\begin{tabular}{|c|c|c|}
\hline Risk factor & Definition / Composition & Duration \\
\hline CDI & $\begin{array}{l}\text { Clinical symptoms (diarrhea) } \\
+ \text { Clinical signs (pathologic findings by endoscopy or radiology) } \\
\text { + Pathogen isolation (culture, or antigen) and } C \text {. difficile-toxin }\end{array}$ & $\begin{array}{l}\text { Permanent exposure after } \\
\text { occurrence }\end{array}$ \\
\hline $\begin{array}{l}\text { Surgical } \\
\text { complications }\end{array}$ & $\begin{array}{l}\text { - Transplant specific vascular complications: } \\
\text { - Liver: arterial or portal vein thrombosis/leak } \\
\text { - Lung: bronchial arterial or venous thrombosis/leak } \\
\text { - Heart: acute ischemia or coronary heart disease } \\
\text { - Kidney: renal artery or venous thrombosis/leak } \\
\\
\text { - Transplant specific anastomotic complications: } \\
\text { - Liver: biliary stenosis/leak" } \\
\text { - Lung: bronchial stenosis/dehiscence } \\
\text { - Kidney: ureter stenosis/leak } \\
\text { - Biopsy related complications } \\
\text { - Hemorrhagic complications }\end{array}$ & $\begin{array}{l}\text { Exposure for } 6 \text { months after } \\
\text { occurrence }\end{array}$ \\
\hline $\begin{array}{l}\text { Medical } \\
\text { problems* }\end{array}$ & $\begin{array}{l}\text { - Tumor in transplant (liver/lung) } \\
\text { - Arrhythmia or valvulopathy (heart) } \\
\text { - Renal failure (not kidney) } \\
\text { - Recurrence of initial disease leading to transplant }\end{array}$ & $\begin{array}{l}\text { - Arrhythmia/valvulopathy: } \\
\text { exposure for } 1 \text { month } \\
\text { after occurrence } \\
\text { - Tumor, recurrence of initial } \\
\text { disease, renal } \\
\text { failure: permanent } \\
\text { exposure after occurrence }\end{array}$ \\
\hline Rejection & Biopsy proven and treated rejections & $\begin{array}{l}\text { Exposure for } 1 \text { month after } \\
\text { occurrence }\end{array}$ \\
\hline Infections & $\begin{array}{l}\text { Bacterial infections: } \\
\text { - proven infections in the transplant } \\
\text { - bacteremia } \\
\text { - } \quad \text { Fungal infections: } \\
\text { - fungemia } \\
\text { - all transplants: probable/proven infections due to } \\
\text { Aspergillus spp./Zygomycetes spp. } \\
\text { - Liver: Candida spp. } \\
\text { - Lung: Pneumocystis } \\
\text { - Proven viral infections in the transplant: } \\
\text { - Liver: hepatitis B/ C viruses } \\
\text { - Lung: respiratory viruses }{ }^{+} \\
\text {- Kidney: BK polyomavirus } \\
\text { Probable/proven CMV disease/CMV syndrome }\end{array}$ & $\begin{array}{l}\text { - Aspergillus, Zygomycetes } \\
\text { hepatitis B and C, BKV and } \\
\text { CMV: permanent exposure after } \\
\text { occurrence } \\
\text { - All other infections: } \\
\text { exposure for } 1 \text { month } \\
\text { after occurrence }\end{array}$ \\
\hline
\end{tabular}

${ }^{+}$Respiratory viruses: Adenovirus, Influenza, Parainfluenza, Metapneumovirus, Rhinovirus and RSV

* Diabetes and hypertension were analyzed individually

This article is protected by copyright. All rights reserved. 
Table 6. Risk of death and graft loss of SOT recipients with CDI

\begin{tabular}{|c|c|c|c|c|}
\hline & \multicolumn{2}{|c|}{ Mortality analysis } & \multicolumn{2}{|c|}{ Graft loss analysis } \\
\hline & $\begin{array}{c}\text { Univariate } \\
\text { HR [95\% Cl] } \\
\text { p-value }\end{array}$ & $\begin{array}{c}\text { Multivariable } \\
\text { HR [95\% Cl] } \\
\text { p-value }\end{array}$ & $\begin{array}{c}\text { Univariate } \\
\text { HR [95\% Cl] } \\
\text { p-value }\end{array}$ & $\begin{array}{c}\text { Multivariable } \\
\text { HR [95\% Cl] } \\
\text { p-value }\end{array}$ \\
\hline \multicolumn{5}{|l|}{ Baseline characteristics } \\
\hline $\begin{array}{l}\text { Recipient's age at SOT } \\
\text { (years) }\end{array}$ & $\begin{array}{c}1.03[1.02,1.05] \\
<0.001\end{array}$ & $\begin{array}{c}1.04[1.03,1.05] \\
<0.001\end{array}$ & $\begin{array}{c}1.01[1.00,1.02] \\
0.16\end{array}$ & \\
\hline Male vs. Female & $\begin{array}{c}1.09[0.82,1.46] \\
0.55\end{array}$ & & $\begin{array}{c}1.04[0.73,1.49] \\
0.83\end{array}$ & \\
\hline Type of transplant & $<^{-[-]}$ & $<{ }^{-[-]}{ }^{-0.001^{\circ}}$ & $\begin{array}{c}-[-] \\
0.83^{\circ}\end{array}$ & \\
\hline - heart vs kidney & $\begin{array}{c}3.90[2.51,6.06] \\
<0.001\end{array}$ & $\begin{array}{c}4.36[2.81,6.79] \\
<0.001\end{array}$ & $\begin{array}{c}1.33[0.72,2.44] \\
0.36\end{array}$ & \\
\hline - liver vs kidney & $\begin{array}{c}2.77[1.95,3.92] \\
<0.001\end{array}$ & $\begin{array}{c}2.81[1.98,3.99] \\
<0.001\end{array}$ & $\begin{array}{c}0.99[0.64,1.54] \\
0.97\end{array}$ & \\
\hline - lung vs kidney & $\begin{array}{c}4.77[3.29,6.90] \\
<0.001\end{array}$ & $\begin{array}{c}4.96[3.41,7.20] \\
<0.001\end{array}$ & $\begin{array}{c}1.02[0.57,1.84] \\
0.94\end{array}$ & \\
\hline Diabetes & $\begin{array}{c}1.22[0.80,1.88] \\
0.354\end{array}$ & & & \\
\hline Hypertension & $\begin{array}{c}0.82[0.58,1.16] \\
0.258\end{array}$ & & & \\
\hline \multicolumn{5}{|c|}{ Time-dependent risk factors ${ }^{\S}$} \\
\hline $\begin{array}{l}\text { Clostridium infection } \\
\text { (CDI) }\end{array}$ & $\begin{array}{c}2.31[1.33,3.99] \\
0.003 \\
\end{array}$ & $\begin{array}{c}1.63[0.94,2.83] \\
0.085 \\
\end{array}$ & $\begin{array}{c}3.72[1.92,7.20] \\
<0.001\end{array}$ & $\begin{array}{c}2.24[1.15,4.37] \\
0.02 \\
\end{array}$ \\
\hline Surgical complications & & & $\begin{array}{c}11.99[7.71,18.64] \\
<0.001\end{array}$ & $\begin{array}{c}7.22[4.53,11.50] \\
<0.001\end{array}$ \\
\hline Medical problems & & & $\begin{array}{c}3.54[2.01,6.23] \\
<0.001\end{array}$ & $\begin{array}{c}2.35[1.33,4.15] \\
0.003\end{array}$ \\
\hline Rejection & & & $\begin{array}{c}10.58[6.67,16.77] \\
<0.001\end{array}$ & $\begin{array}{c}7.56[4.70,12.18] \\
<0.001\end{array}$ \\
\hline Relevant infections & & & $\begin{array}{c}3.01[1.92,4.71] \\
<0.001\end{array}$ & \\
\hline - bacterial / fungal & & & $\begin{array}{c}4.90[3.01,8.00] \\
<0.001\end{array}$ & $\begin{array}{c}3.67[2.22,6.06] \\
<0.001\end{array}$ \\
\hline bacterial only & & & $\begin{array}{c}2.32[1.12,4.81] \\
0.02\end{array}$ & \\
\hline bacteremia only & & & $\begin{array}{c}8.22[4.53,14.92] \\
<0.001\end{array}$ & \\
\hline - fungal only & & & $\begin{array}{c}7.05[2.23,22.33] \\
<0.001\end{array}$ & \\
\hline fungemia only & & & $\begin{array}{c}7.19[1.00,51.89] \\
0.05\end{array}$ & \\
\hline - viral (incl. CMV) & & & $\begin{array}{c}1.58[0.73,3.44] \\
0.25\end{array}$ & \\
\hline viral only & & & $\begin{array}{c}0.75[0.10,5.36] \\
0.77\end{array}$ & \\
\hline CMV only & & & $\begin{array}{c}1.89[0.82,4.37] \\
0.14\end{array}$ & \\
\hline
\end{tabular}

- Test result from Wald (overall) test without estimates

$\S$ Risk factors which may be observed multiple times post-SOT over time until death and/or graft loss.

This article is protected by copyright. All rights reserved. 


\section{Figures}

Figure 1: Cumulative incidences of first CDI episodes according to transplant

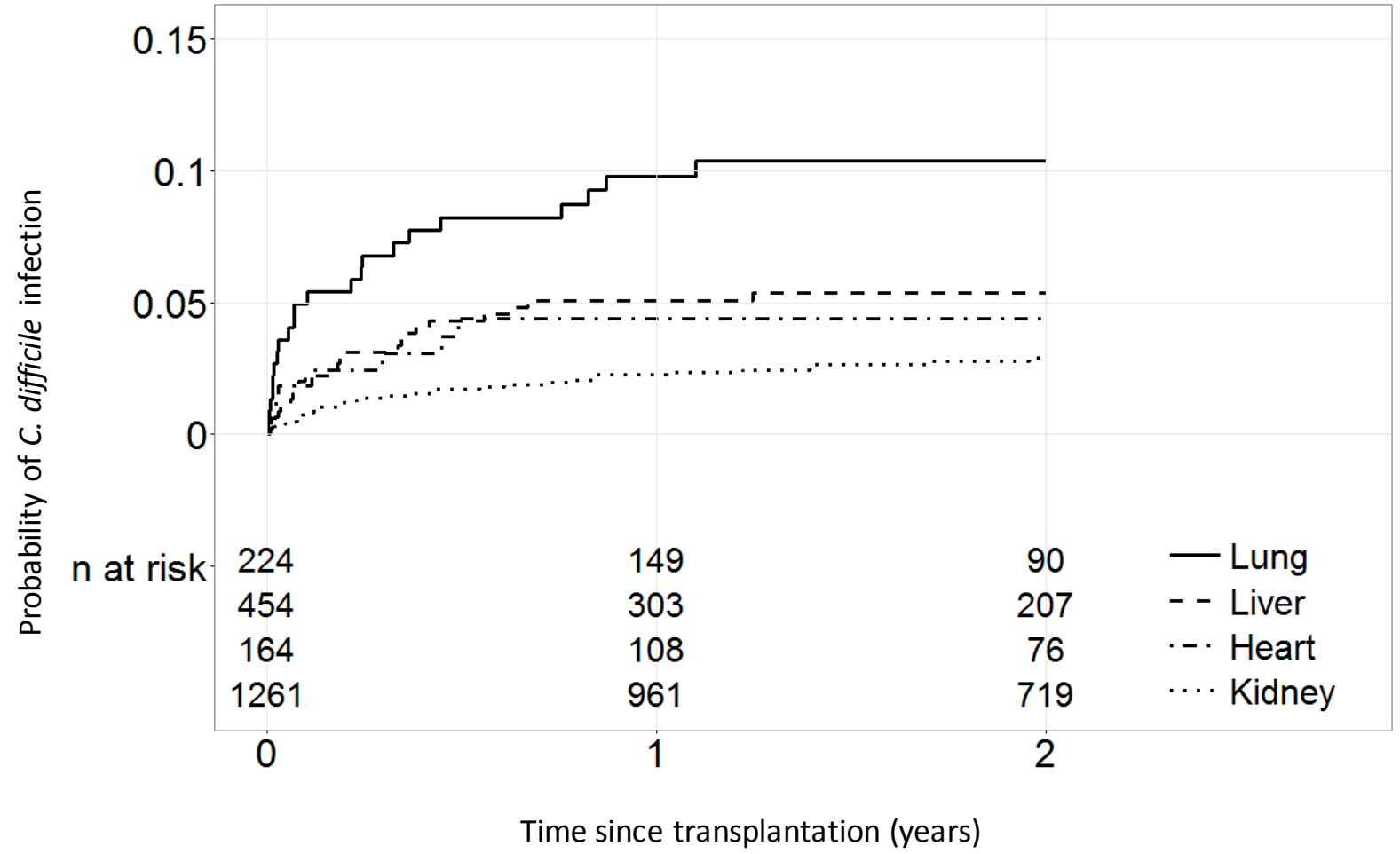

This article is protected by copyright. All rights reserved. 


\section{References}

1. Davies KA, Longshaw CM, Davis GL et al. Underdiagnosis of Clostridium difficile across Europe: the European, multicentre, prospective, biannual, point-prevalence study of Clostridium difficile infection in hospitalised patients with diarrhoea (EUCLID). Lancet Infect Dis 2014;14(12):1208-1219.

2. Riddle DJ, Dubberke ER. Clostridium difficile infection in solid organ transplant recipients. Current opinion in organ transplantation 2008;13(6):592-600.

3. Alonso CD, Kamboj M. Clostridium difficile Infection (CDI) in Solid Organ and Hematopoietic Stem Cell Transplant Recipients. Current infectious disease reports 2014;16(8):414.

4. Pant C, Anderson MP, O'Connor JA et al. Association of Clostridium difficile infection with outcomes of hospitalized solid organ transplant recipients: results from the 2009 Nationwide Inpatient Sample database. Transpl Infect Dis 2012;14(5):540-547.

5. Boutros M, Al-Shaibi M, Chan G et al. Clostridium difficile colitis: increasing incidence, risk factors, and outcomes in solid organ transplant recipients. Transplantation 2012;93(10):1051-1057.

6. Paudel S, Zacharioudakis IM, Zervou FN et al. Prevalence of Clostridium difficile infection among solid organ transplant recipients: a meta-analysis of published studies. PloS one 2015;10(4):e0124483.

7. Lee JT, Kelly RF, Hertz MI et al. Clostridium difficile infection increases mortality risk in lung transplant recipients. J Heart Lung Transplant 2013;32(10):1020-1026.

8. Dallal RM, Harbrecht BG, Boujoukas AJ et al. Fulminant Clostridium difficile: an underappreciated and increasing cause of death and complications. Ann Surg 2002;235(3):363-372.

9. Len O, Rodriguez-Pardo D, Gavalda $\mathrm{J}$ et al. Outcome of Clostridium difficileassociated disease in solid organ transplant recipients: a prospective and multicentre cohort study. Transpl Int 2012;25(12):1275-1281.

10. Gellad ZF, Alexander BD, Liu JK et al. Severity of Clostridium difficile-associated diarrhea in solid organ transplant patients. Transp/ Infect Dis 2007;9(4):276-280.

11. Tsapepas DS, Martin ST, Miao J et al. Clostridium difficile infection, a descriptive analysis of solid organ transplant recipients at a single center. Diagnostic microbiology and infectious disease 2015;81(4):299-304.

12. Surawicz CM, Brandt LJ, Binion DG et al. Guidelines for diagnosis, treatment, and prevention of Clostridium difficile infections. Am J Gastroenterol 2013;108(4):478-498; quiz 499.

This article is protected by copyright. All rights reserved. 
13. Debast SB, Bauer MP, Kuijper EJ, European Society of Clinical M, Infectious D. European Society of Clinical Microbiology and Infectious Diseases: update of the treatment guidance document for Clostridium difficile infection. Clin Microbiol Infect 2014;20 Suppl 2:126.

14. Zar FA, Bakkanagari SR, Moorthi KM et al. A comparison of vancomycin and metronidazole for the treatment of Clostridium difficile-associated diarrhea, stratified by disease severity. Clin Infect Dis 2007;45(3):302-307.

15. Louie TJ, Miller MA, Mullane KM et al. Fidaxomicin versus vancomycin for Clostridium difficile infection. N Engl J Med 2011;364(5):422-431.

16. Cornely $\mathrm{OA}$, Crook DW, Esposito $\mathrm{R}$ et al. Fidaxomicin versus vancomycin for infection with Clostridium difficile in Europe, Canada, and the USA: a double-blind, non-inferiority, randomised controlled trial. Lancet Infect Dis 2012;12(4):281-289.

17. Koller MT, van Delden C, Muller NJ et al. Design and methodology of the Swiss Transplant Cohort Study (STCS): a comprehensive prospective nationwide long-term followup cohort. European journal of epidemiology 2013;28(4):347-355.

18. Bucheli E, Kralidis G, Boggian K et al. Impact of enterococcal colonization and infection in solid organ transplantation recipients from the Swiss Transplant Cohort Study. Transpl Infect Dis 2014;16(1):26-36.

19. Hensgens MP, Goorhuis A, Dekkers OM et al. Time interval of increased risk for Clostridium difficile infection after exposure to antibiotics. I Antimicrob Chemother 2012;67(3):742-748.

20. De Pauw B, Walsh TJ, Donnelly JP et al. Revised definitions of invasive fungal disease from the European Organization for Research and Treatment of Cancer/Invasive Fungal Infections Cooperative Group and the National Institute of Allergy and Infectious Diseases Mycoses Study Group (EORTC/MSG) Consensus Group. Clin Infect Dis 2008;46(12):1813-1821.

21. Bauer MP, Notermans DW, van Benthem BH et al. Clostridium difficile infection in Europe: a hospital-based survey. Lancet 2011;377(9759):63-73.

22. Stelzmueller I, Goegele H, Biebl $\mathrm{M}$ et al. Clostridium difficile colitis in solid organ transplantation--a single-center experience. Dig Dis Sci 2007;52(11):3231-3236.

23. Keven $\mathrm{K}$, Basu A, Re L, Tan $\mathrm{H}$ et al. Clostridium difficile colitis in patients after kidney and pancreas-kidney transplantation. Transpl Infect Dis 2004;6(1):10-14.

24. Bunnapradist S, Neri L, Wong $W$ et al. Incidence and risk factors for diarrhea following kidney transplantation and association with graft loss and mortality. Am J Kidney Dis 2008;51(3):478-486.

This article is protected by copyright. All rights reserved. 
25. Friedman-Moraco RJ, Mehta AK, Lyon GM et al.. Fecal microbiota transplantation for refractory Clostridium difficile colitis in solid organ transplant recipients. Am J Transplant 2014;14(2):477-480.

26. van Nood E, Vrieze A, Nieuwdorp $M$ et al. Duodenal infusion of donor feces for recurrent Clostridium difficile. N Engl J Med 2013;368(5):407-415.

27. Dubberke ER, Burdette SD, Practice ASTIDCo. Clostridium difficile infections in solid organ transplantation. Am J Transplant 2013;13 Suppl 4:42-49.

28. Donnelly JP, Wang HE, Locke JE et al. Hospital-onset Clostridium difficile infection among solid organ transplant recipients. Am J Transplant 2015;15(11):2970-2977.

29. McDonald LC, Killgore GE, Thompson A et al. An epidemic, toxin gene-variant strain of Clostridium difficile. N Engl J Med 2005;353(23):2433-2441.

30. Widmer A, Frei R, Kuijper E et al. Clostridium difficile point-prevalence study, Switzerland. In. ECCMID. Vienna, 2017.

This article is protected by copyright. All rights reserved. 